\title{
МЕДИКО-СОЦІАЛЬНІ АСПЕКТИ КАРДІОЛОГІЧНОЇ ПАТОЛОГІЇ У ПАЦІЄНТІВ ОФТАЛЬМОЛОГІЧНОГО ПРОФІЛЮ
}

\author{
І. В. Шахбун, Л. В. Левицька, І. В. Радіонова \\ Медичний офтальмологічний центр, м. Одеса \\ Одеський національний медичний університет \\ ДВНЗ «Тернопільський державний медичний університет \\ імені І. Я. Горбачевського МОЗ України" \\ Криворізький професійний гірничо-металургійний ліщей
}

\begin{abstract}
У статті обгрунтовано актуальність досліджуваної проблеми, передбачено вивчення медико-соціальних аспектів здоров’я населення, підвищення медичної культури та популяризації здорового способу життя, чітких навичок профілактичної роботи медичної сестри у цьому аспекті.
\end{abstract}

\section{MEDICAL-SOCIAL ASPECTS OF CARDIOLOGICAL PATHOLOGY IN PATIENTS OF THE OPHTHALMOLOGICAL PROFILE}

\author{
I. V. Shahbun, L.V. Levytska, I. V. Radionova \\ Medical ophthalmologic center, Odesa \\ Odesa National Medical University \\ I. Horbachevsky Ternopil State Medical University \\ Kryvyi Rih Professional Mining and Metallurgical Lyceum
}

\begin{abstract}
The article substantiates the relevance of the problem under study, provides for the study of medical and social aspects of health of the population, enhancement of medical culture and popularization of a healthy lifestyle, and precise skills of the nurse's preventive work in this aspect.
\end{abstract}

Вступ. Основними причинами порушення зору на сьогодні у світі $\epsilon$ нескоректовані аномалії рефракції (короткозорість, далекозорість або астигматизм) 43 \%; катаракта - 33 \%; глаукома - 2 \%. Близько 65 \% всіх людей, які страждають від порушень зору, - це люди віком 50 років і старше. У цілому, незважаючи на старіння населення, масштаби порушень зору в світі з початку 90-х років зменшилися. Це зниження пояснюється, в основному, зменшенням числа порушень зору в результаті інфекційних хвороб, а також зростанням загального рівня соціально-економічного розвитку, доступу до офтальмологічних послуг, підвищення обізнаності населення щодо вирішення проблем, пов'язаних із порушенням зору (хірургія, пристрої для корекції рефракції та ін.) [1]. Однак, проблема попередження та лікування порушень зору на сьогодні ускладнюється як недостатніми можливостя-

(ㄱ І. В. Шахбун, Л. В. Левицька, І. В. Радіонова, 2017 ми надання сучасних медичних послуг для пацієнтів із низьким соціальним статусом, так і наявністю коморбідної патології (артеріальна гіпертензія, атеросклероз, цукровий діабет). Варто відзначити, що основними категоріями пацієнтів офтальмологічних клінік в Україні $є$ хворі на катаракту, глаукому і ретинопатію внаслідок серцево-судинної патології, в першу чергу, гіпертонічної хвороби, а також цукрового діабету [2]. Актуальним є вивчення поширеності серцево-судинних захворювань (ССЗ) серед пацієнтів, які лікуються в офтальмологічній клініці, можливостей підвищення ефективності лікування, збільшення тривалості життя та покращення його якості, а також роль медичної сестри у цьому процесі.

Основна частина. Серцево-судинні захворювання $\epsilon$ однією із складних та актуальних проблем світової охорони здоров'я. За даними статистики серцевосудинної захворюваності та смертності останніх деся- 
тиліть в Україні сформувався тип здоров'я населення, який порівняно з розвинутими країнами Євросоюзу характеризується зниженням середньої тривалості життя на 10-12 років, значним збільшенням серцевосудинної захворюваності та підвищенням смертності від СС3, частка яких складає 63 \% від усіх причин смерті [3]. Саме тому на сьогодні в Україні хвороби системи кровообігу були і залишаються однією з головних медико-соціальних проблем системи охорони здоров'я, і, зрозуміло, що потребують нагального втручання інституцій охорони здоров'я для покращення цієї ситуації.

Серед усіх ССЗ найпоширенішими є ішемічна хвороба серця, друге місце посідає цереброваскулярна патологія, від якої, на жаль, помирає кожний третій пацієнт у цій групі. Третє місце серед усіх хвороб системи кровообігу займає гіпертонічна хвороба $[4,5]$. Хвороби органів кровообігу мають значне поширення, часто призводять до повної втрати працездатності. Такі серцево-судинні захворювання як гіпертонічна хвороба, атеросклероз та ішемічна хвороба серця становлять так звану групу «соціальних хвороб», тобто винуватцями яких $є$ хронічний стрес, гіподинамія, або малорухливість, надлишкова маса тіла внаслідок нераціонального харчування та тютюнокуріння [3, 6].

Питання профілактики в усьому світі $є$ основною стратегією збільшення тривалості життя населення. Регулювання факторів ризику (ФР) може знизити клінічні прояви і рівень передчасної смертності серед осіб із серцево-судинними захворюваннями. Найдієвішими заходами, здатними вплинути на ризик розвитку СС3, є ті, що спрямовані на регулювання модифікованих факторів кардіоваскулярного ризику [6-8]. В Європейських рекомендаціях із профілактики ССЗ у клінічній практиці задекларовано необхідність проведення профілактичних заходів впродовж усього життя. Основними стратегіями популяційної профі-

\section{СПИСОК ЛІТЕРАТУРИ}

1. Vision Loss Expert Group. Magnitude, temporal trends, and projections of the global prevalence of blindness and distance and near vision impairment: a systematic review and meta-analysis / R. R. A. Bourne, S. R. Flaxman, T. Braithwaite [et al.] ; Lancet Glob. Health. - 2017. - Vol. 5 (9). - P. 888-897. http://www.who.int/mediacentre/factsheets/fs282/en/

2. Варивончик Д. В. Світові епідеміологічні характеристики поширеності порушень зору / Д. В. Варивончик // Міжнародний науково-практичний журнал «Офтальмологія». - 2016. - № 1 (03). лактики на сьогодні вважають виявлення та контроль факторів ризику серцево-судинних захворювань, а також проведення освітніх програм для населення. Ефективна профілактика ССЗ включає:

1. Виявлення чинників, захворювань та станів, що можуть мати негативний вплив на розвиток ССЗ та визначають рівень загального ризику ССЗ.

2. Корекцію (немедикаментозну та медикаментозну) ФР, що піддаються модифікації упродовж життя.

3. Навчання пацієнтів із питань профілактики ССЗ, залучення їх до моніторингу ФР, підтримання у них мотивації щодо дотримання здорового способу життя та рекомендацій лікаря.

У Клінічній настанові з профілактики ССЗ Європейського товариства кардіологів 2016 р., перелік заходів корекції з доведеною ефективністю включає відмову від тютюнокуріння, дотримання засад здорового харчування, підтримку адекватного рівня фізичної активності, корекцію психосоціальних ФР, підтримку оптимальної маси тіла, нормалізацію рівня артеріального тиску, нормалізацію рівня ліпідів. Обов'язковою складовою заходів щодо корекції ФР $\epsilon$ навчання пацієнтів з питань здорового способу життя, попередження ССЗ, підтримання у них мотивації щодо збереження здоров'я та дотримання рекомендацій лікаря [7-9].

Висновки. 1. Існуюча доказова база свідчить про те, що дотримання засад здорового способу життя та корекція факторів ризику мають позитивний вплив на попередження розвитку серцево-судинних захворювань та їх ускладнень у пацієнтів офтальмологічного профілю.

2. Обґрунтованим $є$ надання інформації щодо профілактики факторів ризику серцево-судинних захворювань медичними сестрами закладів охорони здоров'я, у тому числі офтальмологічного профілю, та навчання пацієнтів основам здорового способу життя.

3. Медико-соціальні аспекти хвороб системи кровообігу: аналітично-статистичний посібник / [уклад. Т. С. Манойленко, І. Л. Ревенько, А. В. Гандзюк] ; за ред. В. М. Коваленка, В. М. Корнацького. - К. : МВЦ «Медінформ», 2009. - 146 с.

4. Коваленко В. М. Кардіологічна допомога //У кн. Панорама охорони здоров'я населення України / А. В. Підаєв, О. Ф. Возіанов, В. Ф. Москаленко [та ін.]. - К. : Здоров'я, 2003. - С. 216-218.

5. Корнацький В. М. Хвороби системи кровообігу і психічне здоров'я / В. М. Корнацький, В. І. Клименко. - К. : МВЦ «Медінформ», 2009. - 176 с. 
6. Демографія і стан здоров'я народу України : аналітично-статистичний посібник / В. М. Коваленко, В. М. Корнацький, Т. С. Манойленко та співавт. - К., 2013. - 146 с.

7. Уніфікований клінічний протокол первинної, вторинної (спеціалізованої) та третинної (високоспеціалізованої) медичної допомоги (УКПМД) «Профілактика серцево-судинних захворювань» (2016) [Електронний ресурс]. - Режим доступу : http://mtd.dec.gov.ua/images/ dodatki/2016_564_PSSZ/2016_564_YKPMD_PSSZ.pdf.

8. 2016 European Guidelines on cardiovascular disease prevention in clinical practice: The Sixth Joint Task Force of the European Society of Cardiology and Other Societies on Cardiovascular Disease Prevention in Clinical Practice (constituted by representatives of 10 societies and by invited experts) /European Heart Journal, Volume 37, Issue 29, 1 August 2016, Pages 2315-2381, https://doi.org/10.1093/ eurheartj/ehw106

9. Серцево-судинна захворюваність в Україні та рекомендації щодо покращення здоров'я в сучасних умовах: аналітично-статистичний посібник / В. М. Корнацький, А. П. Дорогой, Т. С. Манойленко та співавт. - К., 2012. $117 \mathrm{c}$.

Отримано 15.11.17 